\title{
Vascular microsurgery course: 40 years at the Centro Médico Nacional 20 de Noviembre (ISSSTE) and 33 years at the Faculty of Medicine of the UNAM
}

\author{
Curso de microcirugía vascular: 40 años en el Centro Médico Nacional 20 de Noviembre \\ del Instituto de Seguridad y Servicios Sociales de los Trabajadores del Estado y 33 años \\ en la Facultad de Medicina de la Universidad Nacional Autónoma de México
}

\author{
Luis Padilla1,2*, Rubén Argüero², Mauricio Di Silvio, Javier López-Gutiérrez¹, Takeshi Landero, \\ Jorge García ${ }^{2}$ and Pilar Carranza ${ }^{1}$ \\ ${ }^{1}$ Experimental Surgery Department, Centro Médico Nacional 20 de Noviembre, Instituto de Seguridad y Servicios Sociales de los Trabajadores del \\ Estado; ${ }^{2}$ Department of Surgery, Faculty of Medicine, Universidad Nacional Autónoma de México. Mexico City, Mexico
}

\begin{abstract}
On June 1977, "Centro Médico Nacional 20 de Noviembre," in Mexico City, implemented the first vascular microsurgery course. The aim was to develop clinical applications of microsurgery focus on surgical specialties, due to the necessity to develop microsurgical skills. On August 1964 we started the program course at the surgical department of the School of Medicine at Universidad Nacional Autónoma de México (UNAM). Actually, our course is given five times a year at 20 de Noviembre hospital, and four times at the UNAM. One June 2017, the Experimental Surgical Department at "Centro Médico Nacional 20 de Noviembre" reached 40 continuous or uninterrupted years of successfully teaching the microsurgical vascular skills. The aim of this study is to evaluate the satisfaction degree among the students. For that propose, a written survey was applied one year later, after successfully completed the course. These results reveal a satisfaction rate of $80 \%$ among these students.
\end{abstract}

KEY WORDS: Vascular. Microsurgery. Course.

\section{Resumen}

El Curso de Microcirugía Vascular (CMV) inició en el Centro Médico Nacional (CMN) 20 de Noviembre en la Ciudad de México, en junio de 1977, con la idea de poder desarrollar aplicaciones clínicas de microcirugía en todas las especialidades quirúrgicas. En vista de la gran demanda hacia la microcirugía como destreza, en agosto de 1984 iniciamos el programa de Microcirugía Vascular en el Departamento de Cirugía de la Facultad de Medicina de la Universidad Nacional Autónoma de México (UNAM). El CMV se imparte cinco veces al año en el CMN 20 de Noviembre del Instituto de Seguridad y Servicios Sociales de los Trabajadores del Estado y cuatro en la Facultad de Medicina de la UNAM. En junio de 2017, el Servicio de Cirugía Experimental del CMN 20 de Noviembre cumple 40 años ininterrumpidos de impartir con éxito el CMV. Con el fin de evaluar el CMV de acuerdo con el nivel de satisfacción, a partir de 2016 se implementó el uso de un cuestionario. La finalidad es dar seguimiento repitiendo el cuestionario un año después para valorar las habilidades adquiridas. Los porcentajes demuestran que más del $80 \%$ de los alumnos están satisfechos con las destrezas adquiridas en el CMV.

PALABRAS CLAVE: Curso. Microcirugía. Vascular.

\author{
Correspondence: \\ *Luis Padilla \\ San Lorenzo, 502 \\ Col. del Valle, Del. Benito Juárez \\ C.P. 03229, Ciudad de México, México \\ E-mail: cir.exp.20nov@gmail.com
}

Date of reception: 06-12-201

Date of acceptance: 26-03-2018

DOI: 10.24875/CIRUE.M18000029
Cir Cir. 2018;86:177-184

Contents available at PubMed www.cirugiaycirujanos.com 


\section{Introduction}

We can define microsurgery as the magnification of an operating field that allows the dissection and repair of tissues with quality and precision through different optical systems, such as magnifying glasses, teleloupe spectacles, endoscopic surgery lenses and surgical microscope.

In all surgical specialties (general surgery, vascular surgery, reconstructive surgery, urology, neurosurgery, pediatric surgery, gynecology and others), microsurgery should not be recognized as a specialty, but as an indispensable surgical technique in routine practice of all surgeon specialists.

Microsurgery courses must take place in high-quality units that offer the necessary equipment to carry out surgical practices, which makes having a microscope, microinstrument tray, microsutures and laboratory rats or mice as biological material essential. It is also important for the student to have access to videos on basic, experimental and clinical cases' microsurgical procedures, as well as updated bibliographic material.

Training on microsurgery techniques requires weII-structured courses that offer theoretical knowledge and demonstrations by expert teachers, in addition to the opportunity for continuous training.

Not all hospital institutions have experimental surgery laboratories and microsurgery units where to train specialists in this discipline.

The present article describes 40 uninterrupted years of teaching the Vascular Microsurgery Course (VMC) at the Experimental Surgery Department of the 20 de Noviembre National Medical Center (CMN - Centro Médico Nacional), of the Institute of Security and Social Services of State Workers (ISSSTE - Instituto de Seguridad y Servicios Sociales de los Trabajadores del Estado), and 33 years in the Department of Surgery of the Faculty of Medicine of the National Autonomous University of Mexico (UNAM - Universidad Nacional Autónoma de México).

\section{Background}

The 20 de Noviembre CMN is ISSSTE's flagship hospital, which provides medical care mainly in high specialty medicine, with clinical and surgical services offered by nationally and internationally recognized specialists.

The educational area is under the responsibility of the Teaching and Research Sub-directorate, which manages human capital and material resources aimed at promoting learning and research activities in basic and clinical areas. Each year, 10 specialty postgraduate courses are carried out, as well as more 30 subspecialty postgraduate courses and around 20 high-specialty courses, in addition to 22 undergraduate courses pertaining to six educational institutions ${ }^{1}$.

Formal professional teaching development is essential to the achievement of learning objectives in health, which clearly has an impact on patient care quality. ${ }^{1}$

\section{Beginning of the Vascular Microsurgery Course}

In July 1976, the $4^{\text {th }}$ International Microsurgical Society Congress was held at Instituto Nacional de Nutrición Salvador Zubirán in Mexico City, organized by Dr. Federico Chávez Peón (Fig. 1 a and Table 1), then Head of the Transplantation Unit, with the experimental microsurgery demonstrations (Surgical Skill Station) standing out. Five tables were implemented at the Department of Experimental Surgery, where Dr. Sun Lee (Fig. 1b), father of experimental microsurgery $^{2}$, and other microsurgery pioneers of other countries, developed different models among which end-to-end anastomosis of the abdominal aorta, endto-side portocava bypass, heterotopic renal auto-transplantation, heterotopic cardiac allotransplantation and orthotopic liver allotransplantation in rats as biological material stand out. The impact was so huge, that a group of Mexican surgeons asked Dr. Chávez Peón to design a course with Dr. Sun Lee, which took place from November 21 to 28, 1976 (Fig. 2).

This course prompted several of Dr. Lee's students to organize microsurgery training programs in their respective experimental surgery laboratories at different hospital units, with Dr. Trifón de la Sierra (Fig. $1 \mathrm{c}$ ), Dr. Alberto Chousleb (Fig. 1 d), Dr. Mauro Loyo (Fig. 3 a) and Dr. Rubén Cortés (Fig. 3 b) standing out ${ }^{3}$.

The Vascular Microsurgery Course at 20 de Noviembre CMN in Mexico City started in June 1977 with the support of the then Chief of the Experimental Surgery Department, Dr. Armando Valle (Fig. 3 c), who assigned Dr. Luis Padilla as a full professor (Fig. $3 \mathrm{~d}$ ). The course was taken by five heads of surgical departments, who in turn sent their staff doctors and residents to train in the laboratory with the idea of developing clinical applications for microsurgery. Since then, he implemented the concept of 


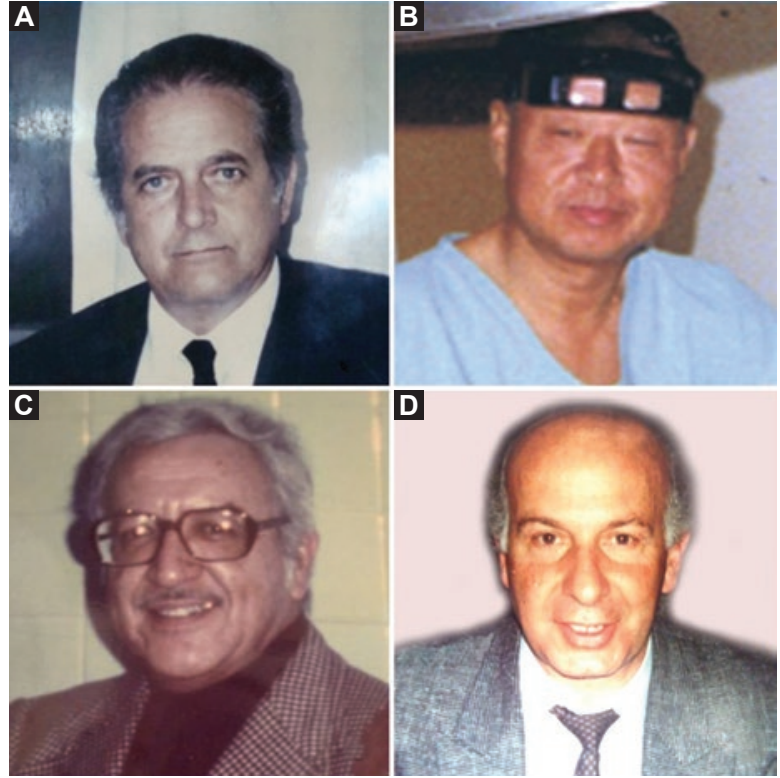

Figure 1. A: Dr. Chávez Peón. Head of the Transplantation Unit, Instituto Nacional de Nutrición Salvador Zubirán, 1974. B: Dr. Sun Lee. Professor of Experimental Surgery, University of California, San Diego School of Medicine. C: Dr. Trifón de la Sierra. General Surgeon, transplantation pioneer in Mexico, Hospital 20 de Noviembre; Head of the Department of Surgery, UNAM, 1964-1971. D: Dr. Alberto Chousleb. General Surgeon, Professor of Microsurgery Courses, Centro Médico $A B C$ (The American British Cowdray Medical Center).

"Microsurgery Unit", intended to support all surgical services of the hospital in order to solve clinical cases with microsurgery techniques, offering a basic 5-day course and a specific continuous training program according to clinical needs, in addition to supporting emergency procedures. In view of the great demand for microsurgery as a skill, in August 1984, we initiated the same program in the Department of Surgery of the UNAM Faculty of Medicine, with Dr. Alberto Chousleb's initial support. Currently, our VMC is given five times a year at ISSSTE 20 de Noviembre CMN and four times at UNAM Faculty of Medicine ${ }^{3}$

In June 2017, the 20 de Noviembre CMN Experimental Surgery Department celebrated 40 uninterrupted years of successfully teaching the VMC.

\section{Characteristics of the Vascular Microsurgery Course}

The planning, the selection of learning strategies and appropriate evaluation constitute the guiding axis for the success of the training of the doctors the country needs ${ }^{1}$.

The VMC has a 5-day duration. During the first day, we address theoretical topics, such as history

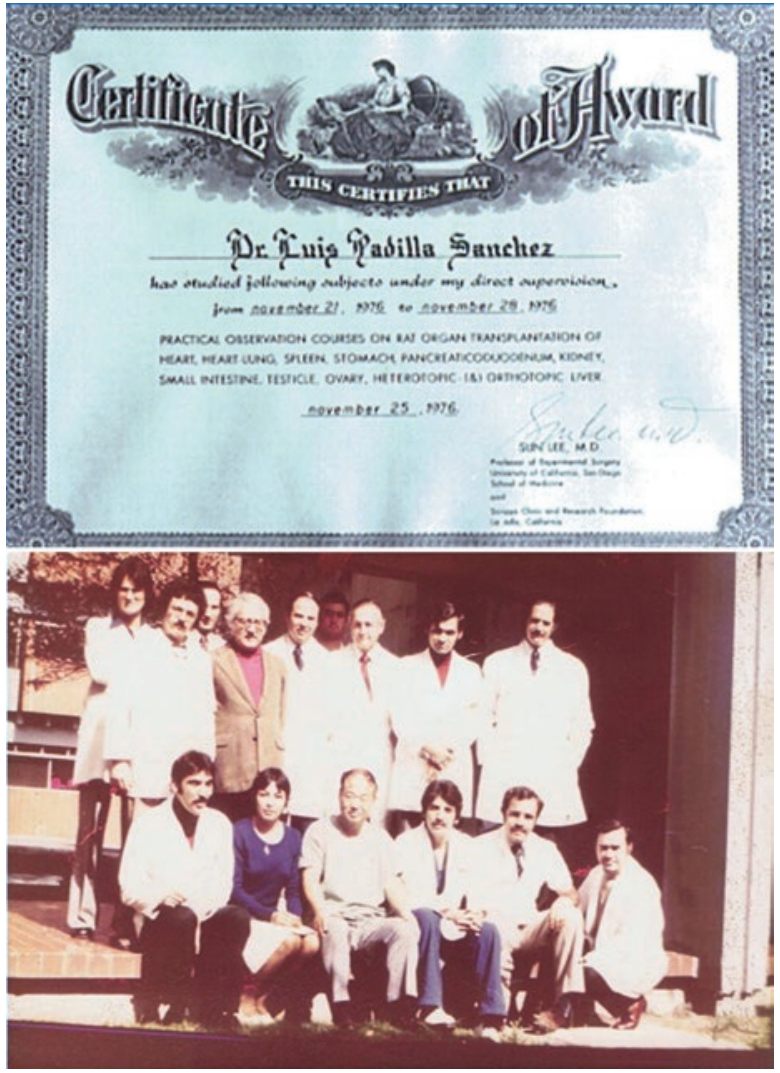

Figure 2. Diploma and participants of the first Microsurgery Course taught by Dr. Sun Lee at the National Institute of Nutrition, November 1976.

of microsurgery, experimental and clinical applications, theoretical bases of vascular microanastomosis techniques, and anatomy, biology and handling of the laboratory rat. Also during the first day, two surgical demonstrations are carried out by an expert teacher: 1) anesthetic management of the rat and exploratory laparotomy with abdominal aorta and cava dissection, and 2) microsurgical knots with microsutures $(7-0,8-0,9-0$ and 10-0) carried out on a training board (latex sheet), using an operating microscope as a magnification system, starting from lower to higher magnification and with suture material from higher to lower caliber. On the second day, we carry out the demonstration of the end-to-end abdominal aortic anastomosis technique, with 8-0 and 9-0 suture material, followed by two repetitions in the morning and two in the afternoon by the students under the supervision of an assistant teacher. On the third day, the technique to be demonstrated is end-to-end abdominal vena cava anastomosis, with 9-0 and 10-0 material, and with the same model repetition schedule, starting with the end-to-end abdominal aorta anastomosis prior to attempting the vena cava repetition at least four times. The fourth 
Tabla 1. Chronology and sites of the microsurgery courses imparted by the International Microsurgical Society (1970-1994)

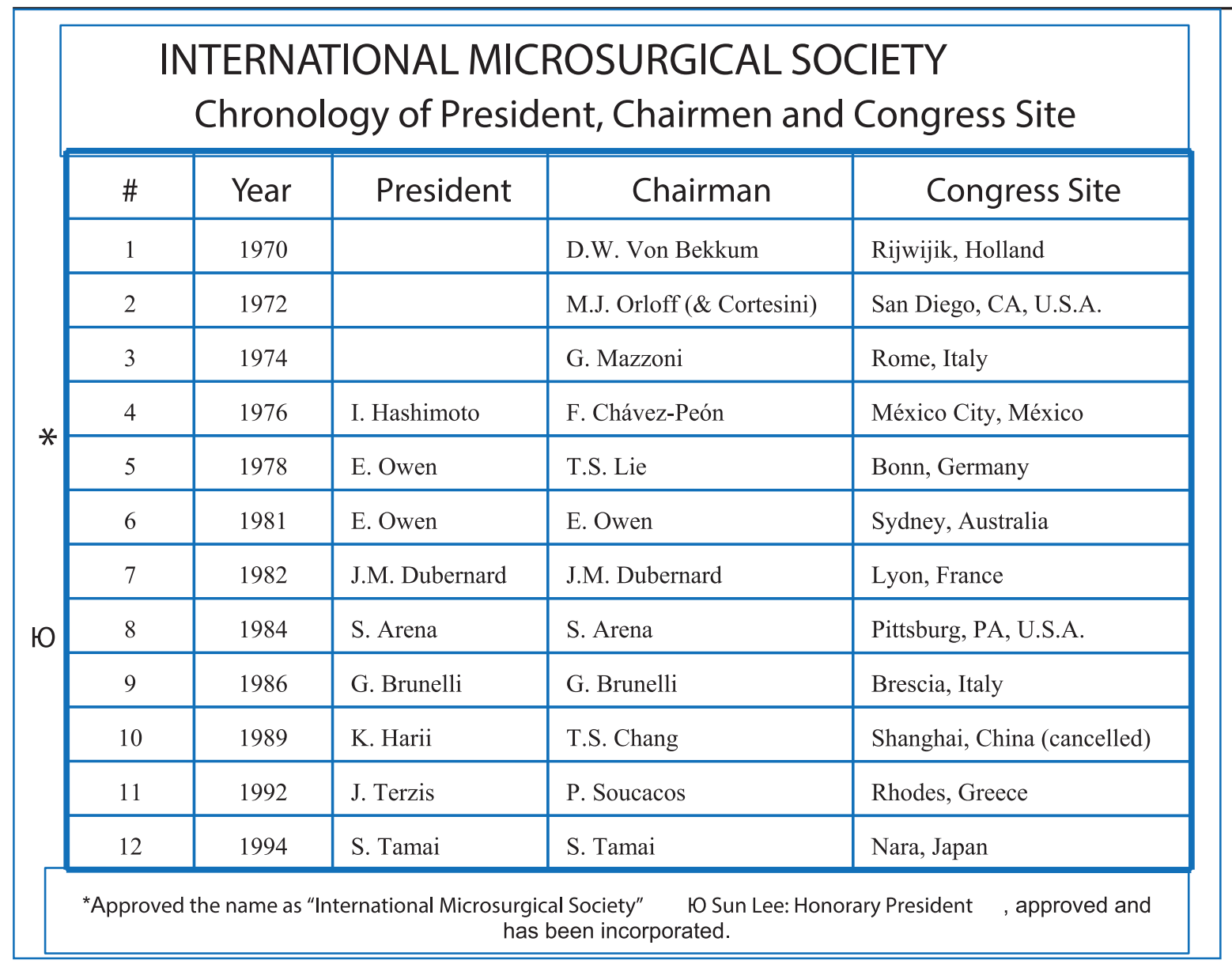

day corresponds to the iliac-iliac artery end-to-side anastomosis technique with 10-0; prior to attempting the iliac anastomosis, the students must repeat the abdominal aorta end-to-end anastomosis model. Finally, on the fifth day, we show the students the femoral artery and vein anastomosis techniques with 10-0 suture material. As in the previous days, repetitions will start with aorta anastomosis followed by the technique in femoral vessels. Edited videos of all techniques can be reviewed on YouTube by requesting "microvascular surgery" (dr.luispadilla. com).

As final evaluation, students are required to perform an abdominal aorta end-to-end anastomosis and to record a video performing patency tests in order to pass the course and receive the recognition diploma. The MVC is endorsed by the 20 de Noviembre CMN, the UNAM Faculty of Medicine, the International Microsurgical Society and the Mexican Academy of Surgery (Fig. 4). Currently, we admit 6-8 students per course in order to provide quality advice and for each one of the students to have their operating microscope and instrument tray ${ }^{3}$.

Microsurgical demonstrations are carried out in a special table with an operating microscope, connected to a monitor in order for the students to observe all the details of the technique and have the possibility to video-record (Fig. 4).

To support the development of the practical sessions and in order for the students to be able to further inquire into details of the techniques, in 1983 we published a Microsurgery Manual that continues to be useful today (Fig. 5) ${ }^{4}$.

In a period of 40 years, we have taught 145 courses and trained 640 students, among surgeons and residents of different surgical specialties, at ISSSTE's 20 de Noviembre CMN; and in the UNAM Faculty of Medicine, in 33 years, we have carried out 113 courses with 568 students $^{3}$.

It is important that hospitals with surgical specialties' training programs for residents have a 


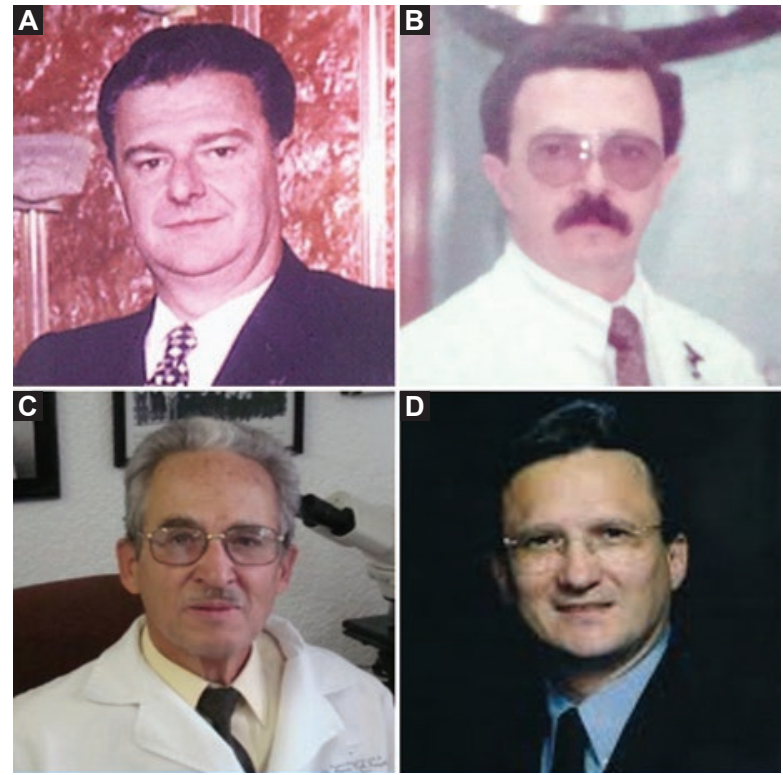

Figure 3. A: Dr. Mauro Loyo. Neurosurgeon, Professor of the Course "Introduction to Microsurgery", CMN Siglo XIX, IMSS, 1977. B: Dr. Rubén Cortés. Surgical oncologist, Professor of Microsurgery Courses, Instituto Nacional de Nutrición Salvador Zubirán. C: Dr. Armado Valle. General surgeon, founder of the ISSSTE 20 de Noviembre CMN Experimental Surgery Department, 1974. D: Dr. Luis Padilla. General surgeon, Head of the ISSSTE 20 de Noviembre CMN Experimental Surgery Department.
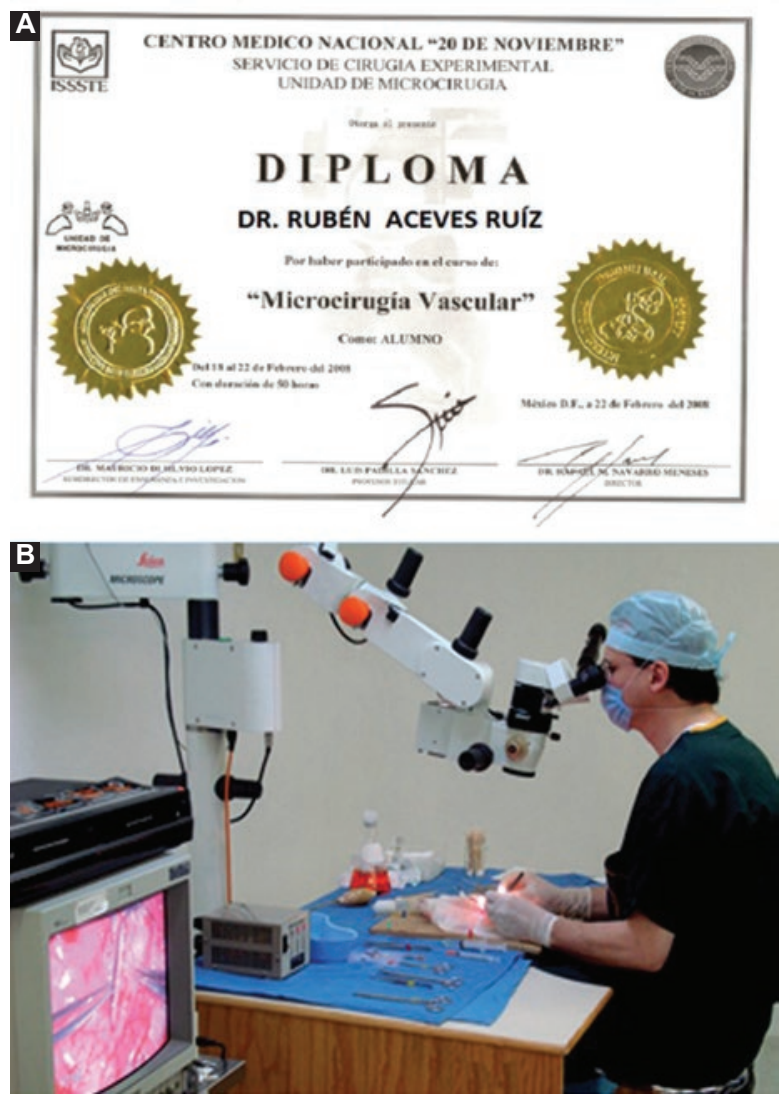

Figure 4. A: Recognition diploma with International Microsurgery Society seal endorsing the course since 1983. B: Surgical model demonstration by expert teacher. microsurgery laboratory in order to be able to develop basic and continuous training courses, as well as the resources to design research protocols and thereby be able to offer patients solutions with microsurgical techniques ${ }^{3}$.

\section{Evaluation of the Vascular Microsurgery Course}

Educational quality is understood as the synthesis of attributes an educational institution or program possess ${ }^{5}$, and is determined by the capacity institutions have to train individuals, in such a way that they can adapt and contribute to the benefit of patient health ${ }^{6}$.

If that which is tried to be measured is the educational quality of a course, it is necessary to establish axes or criteria under which assessing the program is possible (efficacy, efficiency, relevance, significance and equity). According to these criteria, indicators, standards and parameters are constructed or developed, which enable identifying, comparing and grading the characteristics and attributes of the educational program in question ${ }^{5}$.

Effectiveness is understood as the extent to which an educational program achieves its objectives and reaches its goals, while efficiency will be associated with available conditions and resources $^{5}$. The efficacy of an educational program grants legitimacy and accreditation to the institution that applies it, and to achieve this, a continuous evaluation tool that enables to improve the quality of the program is essential. In turn, relevance is related to the satisfaction of social expectations and needs of the program, which measures social impact, i.e. the accumulation of generated contributions ${ }^{7}$.

Another important element is academic relevance, which relates to the quality of the services offered by a program (validity of theories, veracity of knowledge, facts and methods) $)^{8}$.

It is necessary to include two other categories, which are transcendence and equity. A program is transcendent because it produces skills that are useful for the entire life, trains people capable of generating their own learning and creates the skills to extrapolate and transfer solutions from one case to another ${ }^{5}$.

This way, courses in medicine can be measured according to the fulfillment of objectives, the inclusion of valuable and useful contents, to having the 


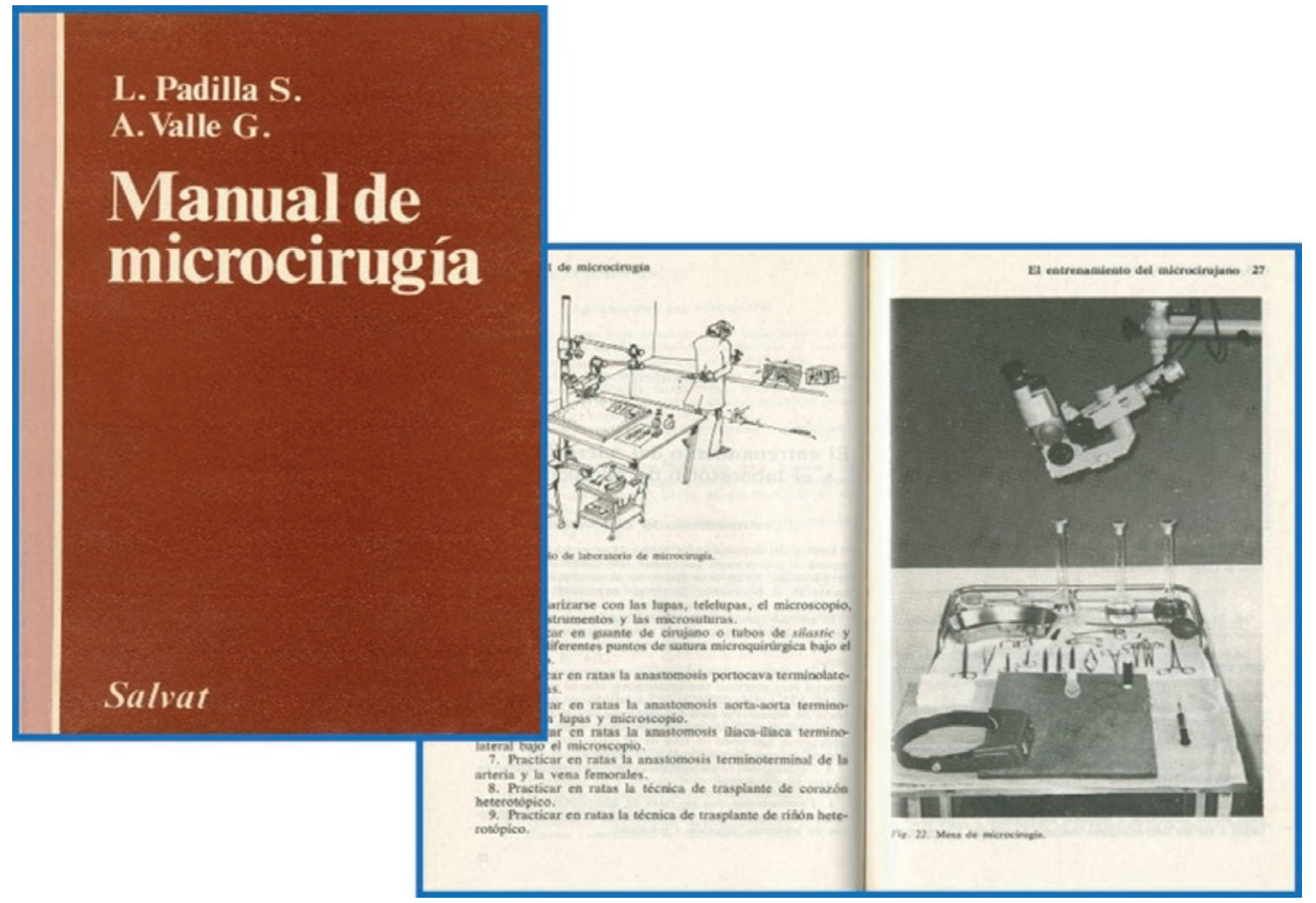

Figure 5. Microsurgery manual (1983).

Table 2. Vascular Microsurgery Course assessment questionnaire

\begin{tabular}{|c|c|c|c|c|}
\hline \multirow{2}{*}{$\begin{array}{l}\text { Questions of the Vascular Microsurgery Course } \\
\text { assessment questionnaire }\end{array}$} & \multicolumn{4}{|c|}{ Answer that better satisfies you } \\
\hline & 1 & 2 & 3 & 3 \\
\hline $\begin{array}{l}\text { What motivated you to take the Vascular Microsurgery } \\
\text { Course? }\end{array}$ & $\begin{array}{l}\text { Requirement in the } \\
\text { place I am assigned to }\end{array}$ & $\begin{array}{l}\text { Interest in starting } \\
\text { training }\end{array}$ & $\begin{array}{l}\text { Interest in improving } \\
\text { treatment }\end{array}$ & $\begin{array}{l}\text { To look for clinical } \\
\text { applications }\end{array}$ \\
\hline $\begin{array}{l}\text { Do you consider that the Vascular Microsurgery Course } \\
\text { lives up to initially promised expectations? }\end{array}$ & Not satisfied at all & Little satisfied & Satisfied & Very satisfied \\
\hline $\begin{array}{l}\text { How much of the techniques demonstrated in the } \\
\text { Vascular Microsurgery Course can be extrapolated to } \\
\text { medical practice? }\end{array}$ & $<25 \%$ & $50 \%$ & $75 \%$ & $100 \%$ \\
\hline $\begin{array}{l}\text { In your professional practice, have you had opportunity } \\
\text { to apply any of the techniques that were demonstrated? }\end{array}$ & No & Once & Twice & $\begin{array}{l}\text { On three or more } \\
\text { occasions }\end{array}$ \\
\hline $\begin{array}{l}\text { In your opinion, do you think that with that which was } \\
\text { demonstrated in the Vascular Microsurgery Course } \\
\text { you could adequately transmit the techniques to other } \\
\text { surgical physicians? }\end{array}$ & No & Unlikely & Probably & Yes \\
\hline $\begin{array}{l}\text { Globally, how do you rate the Vascular Microsurgery } \\
\text { Course? }\end{array}$ & $\mathrm{Bad}$ & Regular & Good & Very good \\
\hline
\end{tabular}

necessary resources and to being capable of generating a positive impact on the care of patients ${ }^{5}$.

The satisfaction of the students who take the course involves a subjective evaluation of the success achieved, since it is focused on perceptions and attitudes rather than on concrete and objective criteria ${ }^{9}$.
VMC objectives are:

- Achieving vascular anastomoses with a caliber equal to or lower than $1 \mathrm{~mm}$ in diameter.

- Learned microsurgical techniques should be able to be reproduced and successfully carried out in clinical practice. 


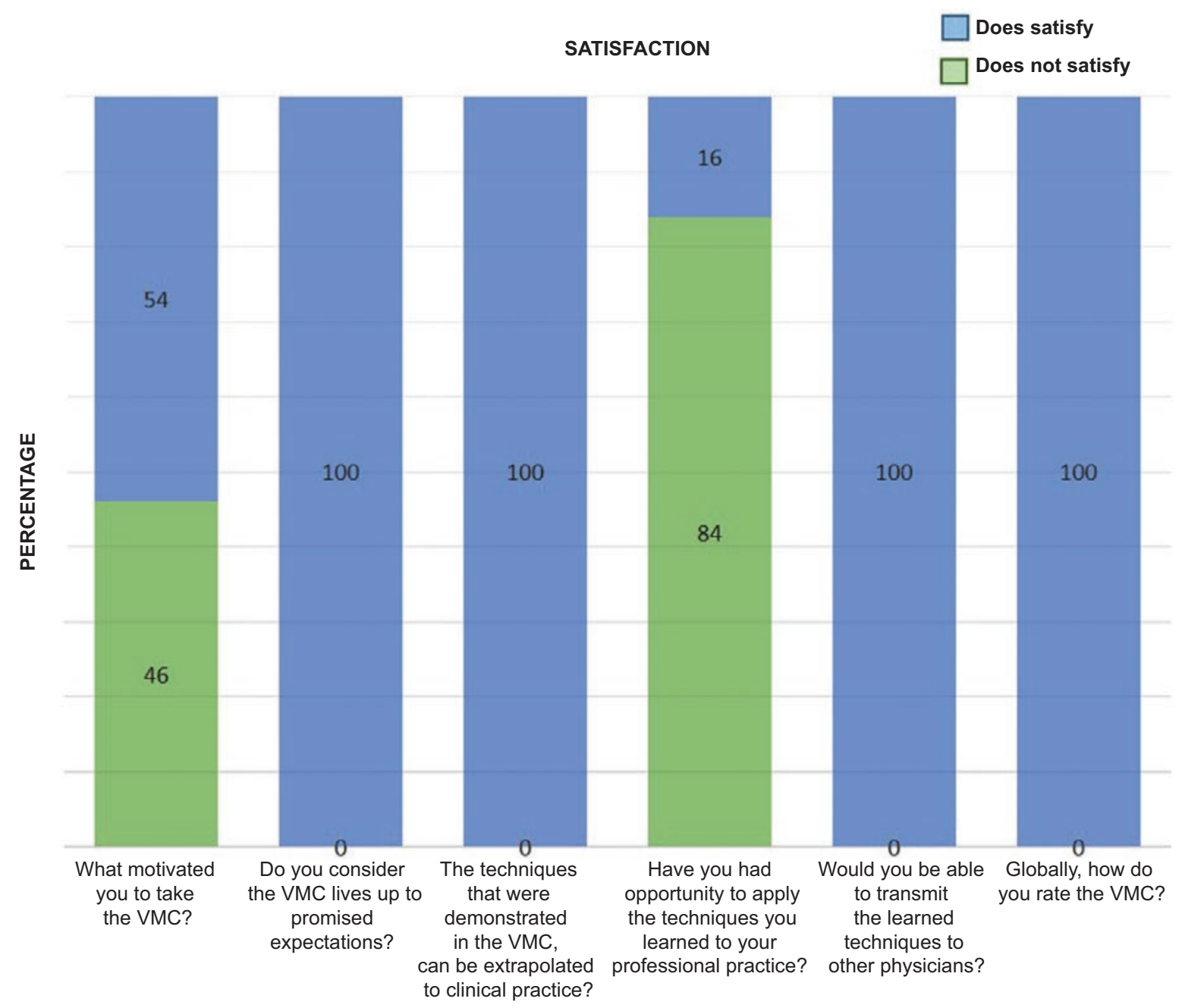

Figure 6. Graph of results.

- Students should be able to transmit this knowledge to other surgeons or residents of different surgical areas.

In order to assess the VMC according to the level of satisfaction, complying with the level of efficacy and efficiency according to the educational program, taking into account the relevance, equity and tolerance required to establish the quality of the course, since 2016, we implemented the use of a questionnaire with a Likert scale (from 1 to 4$)^{10}$ as a measurement instrument, using six items that take into account aspects of motivation, application and reproduction. The purpose is to follow-up the doctors and repeat the questionnaire one year later to assess the acquired skills. These results will be the subject of another publication. The questions asked in the evaluation instrument are shown in table 2.
With the obtained results, we created a database. According to the scale used, we determined that the answers scored as 1 and 2 mean "does not satisfy" (one point of dissatisfaction), while 3 and 4 represent "does satisfy" (the course was considered satisfactory). With these results, we created the graph shown in figure 6 .

\section{Conclusions}

- In 15 years, our Microsurgery Unit directly participated in 121 clinical cases related to seven different specialties, with the participation frequency decreasing as the skills of our trained surgeons and residents grow, which shows that the skills acquired in the VMC are indispensable in the training of surgeons, regardless of their specialty. 
- The efficacy of an educational program grants legitimacy and accreditation to the institution that applies it, and to achieve this, a continuous evaluation tool is essential in order to improve the quality of the program.

- Overall, the figures show that more than $80 \%$ of students are satisfied with VMC efficacy.

- It is important to make improvements to the educational program in the motivation aspect, since only $54 \%$ of students attend on their own interest.

- $100 \%$ of students believe the VMC is applicable in clinical practice.

- $100 \%$ are able to transmit their knowledge and skills to other surgeons.

- It highlights the importance of continuous training to consolidate vascular microsurgery skills.

- Hospitals that maintain resident training programs should have microsurgery laboratories for their teaching and continuous training, where carrying out basic and continuous training courses is possible in order to strengthen their technical skills and, therefore, provide better care to patients.

\section{Conflicts of interest}

The authors declare that there is no conflicts of interest relevant to the performance of this work.

\section{References}

1. Martínez HE, Carranza CP, Aceves MR, Olguín JH. Recursos educativos abiertos en la enseñanza del Centro Médico Nacional "20 de Noviembre". Modelos y estrategias de aprendizaje II. En prensa; 2016.

2. Lee SH, Fisher B. Portocaval shunt in the rat. Surgery. 1961;50:668-72.

3. Padilla SL, Tapia JJ, Goldberg J, Landero YT, Carranza CP, Di Silvio LM. Unidad de Microcirugía: 30 años de experiencia clínica, entrenamiento continuo e investigación. Cirujano General. 2011;33(3).

4. Padilla SL, Valle GA. Manual de microcirugía. México: Salvat; 1983.

5. Cardoso EE, Cerecedo MM. Propuesta de indicadores para evaluar la calidad de un programa de posgrado en educación. Revista Electrónica de Investigación Educativa. 2011;13(2).

6. Marques GP. Impacto de las TIC en la enseñanza universitaria. BarceIona: Departamento de Pedagogía Aplicada, Universidad Autónoma de Barcelona, España; 2008.

7. Cardoso EE, Cerecedo MM, Trejo CC. Evaluación de la organización académico-administrativa de tres programas de posgrado en educación con relación a los parámetros del CONACYT. Tesis doctoral publicada en la Escuela Superior de Comercio y Administración, del Instituto Politécnico Nacional. México D.F.; 2006.

8. Gago A. Apuntes acerca de la evaluación educativa. México: SEP; 2005.

9. Jiménez GA, Terriquez CB, Robles ZF. Evaluación de la satisfacción académica de los estudiantes de la Universidad Autónoma de Nayarit. Revista Fuente. 2011;3(6).

10. Martínez MC. Informe sobre la evaluación de cursos de postgrado del DIEEC/UNED. Madrid, España: Facultad de Educación UNED; 2005. 